\title{
Analysis on the Present Situation of the Printmaking Art in Jilin Province of China
}

\author{
Fu Liü, a , Bing Liü, b, * \\ ${ }^{1}$ Academy of Fine Arts, Northeast Normal University, Changchun130024, China \\ a fuliu6286@163.com, ${ }^{b}$ ice8515@163.com
}

Keywords: Printmaking art; Jilin Province; National printmaking art exhibition; Living environment; Creative level; Current situation of education.

\begin{abstract}
In order to promote the development of printmaking art in Jilin Province, analysis and research with living environment, team situation, institute printmaking teaching scale and awards situation, and carries on the statistics and study of the data. The results show that: In Jilin Province, woodcut print and copper plate print outstanding creation level, but there is a certain gap between the overall development of Zhejiang, Yunnan, Heilongjiang and other provinces, these data statistics and theoretical thinking, for the development of printmaking art in Jilin Province to provide digital support.
\end{abstract}

\section{Analysis of the Present Situation of Living Environment}

From the perspective of the development history of Chinese printmaking art, three changes have happened. For the first time, from 30s to 1949, this is the revolutionary war period, from the beginning of the new woodcut movement initiated by Mr. Lu Xun, woodcut prints to the creation of conditions is simple, economic cost, making fast, for publication and presentation characteristics has been widely attention and use. A variety of newspapers and magazines that are actively published woodcut art works, in order to make the woodcut art in China gradually popular, has played a huge role in the publicity, with its revolutionary and combat, the art of engraving has made brilliant achievements. The second time is from 1950 to the cultural revolution, China in the period of peaceful construction, the development of printmaking art industry depends on the government's official behavior, in terms of human and material resources, the country has given a lot of input, as the main force of political propaganda, printmaking art is an important part of culture and art, during this period, state-owned enterprises, in this period, the provinces and regions, state-owned enterprises have established their own art groups, become the backbone of Chinese printmaking art at that time, the Chinese printmaking art has been pushed to a new height, however, at this time, printmaking art in Jilin Province has not formed a professional group. Third time, this is the thirty years since reform and opening up, Chinese printmaking art have a comprehensive development, through the international exchanges to learn, obtained the advanced technology and the experience, from the state of the art of deviation, it is returned to the normal development stage in accordance with the law of art itself, the public used to call the transition period. The wide field of vision, the renewal of ideas, the progress of technology, coupled with the prosperity and development of cultural policy, making Jilin Province, the printmaking art has made considerable development, during this period, Jilin Province created many influential woodcut print and copper plate print, But the overall development of Heilongjiang, Jiangsu, Zhejiang, Sichuan, Yunnan and other provinces, there is a certain gap [1-3].

Along with the social economy and politics of our country, the original planned economic system has gradually turned to the market economy. Chinese printmaking art from 1996 to enter the market, but compared with other art forms, such as traditional Chinese painting, oil painting, sculpture and so on; printmaking art is in the edge of the art market, lack of market competitiveness. In such a large environment, works of printmaking art in Jilin province rarely, from the strict sense of the art collection is concerned, Jilin Province, has not yet formed a complete printmaking art market system.

\footnotetext{
* Corresponding author: Bing Liu, Associate professor, Northeast Normal University, CHINA. ice8515@163.com.
} 
Printmaking art works are the product of spiritual creation, is the creator of the media to reflect their own value, when the work of the printmaking art changes to social benefits, it is to meet the needs of the spirit of the creator, when the transformation to economic benefits, bring the harvest to the creator, for artists, the two complement each other, are indispensable [4-7]. In the absence of printmaking art market, lack of economic incentives, all kinds of art exhibitions have become the way to show the overall strength of Jilin printmaking art to the society and realize their own value. In addition to the five-year of the "National Art Exhibition", and two-years of the "National Exhibition of Printmaking Art", printmaking art in Jilin Province is rarely able to get the opportunity to show. At present, Jilin Province has not held a large-scale thematic exhibition of printmaking art, compared with other provinces, lack of multi level and multi angle display opportunities, and all kinds of art exhibitions held in Jilin Province, printmaking art works in Jilin Province, the lack of audience, the degree of concern is low.

\section{Analysis of the Status Quo of the Creative Level}

Since 80s of last century, printmaking art in Jilin Province, in the field of vision, the concept of renewal, technological progress, coupled with the prosperity of cultural development policy and other factors, has made great progress, emerged in the Fengge Qi, Sha Ge, Huan Ding, Wenhan Cao, Xiushan Li, Mingsheng Sun, Xiguang Chen, Dunhou Yu, Yifan Li, Lianmin Wang, Min Fan, Shicheng Ji, Miquan Zhang etc., a batch of excellent printmaking art theorist, printmaking artists and printmaking education workers, they are active in the field of printmaking art, made a positive contribution to the development of Chinese printmaking art, at this time, the present situation of the development of the printmaking art in Jilin Province, the level of individual level is high, the overall level is low, copper plate print creation level outstanding, other types of print art performance in general.

\subsection{Analysis of Team Situation.}

In recent years, under the impact of the tide of market economy, the situation of brain drain appeared in Jilin Province, some famous artists and critics go to the developed areas to continue to develop, some printmaking artists will be creative ways to other areas of art, under the economic benefit of the art market, Jilin Province, the older generation of artists gradually retired from work, the realistic situation of the decrease of the number of printmaking art creation ranks in Jilin Province. According to incomplete statistics, at present, in the scope of Jilin Province engaged in the creators of the printmaking art is less than 100 people, the teachers of the college printmaking form the main body of the creative team, these teachers are responsible for the dual task of teaching and creative writing, special status makes a lot of energy into education, on the other hand, must make creative writing in the spare time.

Jilin Province, the decline in the number of printmaking art creative team is an indisputable fact, but we are still happy to see, some young artists, as always, continue to forge ahead, they stick to the printmaking art with calm and mature mentality, shoulder the historical responsibility of the development of printmaking art in Jilin province.

\subsection{Analysis of Awards Situation.}

\subsubsection{Printmaking Art of Jilin Province on "National Art Exhibition"}

The five-yearly congress of "National Art Exhibition", is an important way to show the development of China's fine arts, different forms of art are involved in various provinces, is to focus on the results of the various regions and groups of inspection, in the two national art exhibition in the past ten years, printmaking art works every session of the selected works of Jilin Province, the number of not more than ten, the number of winning entries is zero.

The Ninth "National Art Exhibition" in 1999, a total of 406 pieces of selected works was displayed in the printmaking art works exhibition area. Jilin Province, a total of 8 works selected: "Focus on the forest" of Miquan Zhang, "Sunset" of Shicheng Ji, "Longevity on quartet" of Chao Yan, "Autumn wind of sunflower "of Xiushan Li, "LeLeChe team" of Xiguang Chen, "Storm" of Sha Ge, "Sacrifice 
to save" of Haitao Chen, "sounds of nature" of Lianmin Wang, the number of selected works for the entire exhibition works is $1.97 \%$, ranked 20th in the 28 provinces and groups, compared with the same period in Yunnan Province (26 works), Zhejiang Province (27 works), there is a huge gap.

Five years later, Tenth "National Art Exhibition" held in Sichuan Province, printmaking art works exhibition was on display in various provinces, regions of the work of 381. Jilin Province have a total of 8 works selected: "Soul of populus euphratica" of Sha Ge, "I Ching" of Huaying Li, "Top song of western region" of Lianmin Wang, "Walk with me" of Shicheng Ji, "Multiply and magic" of Xiwen Chen, "Savage civilization" of Yan Wang, "Evocation - four inverted shaman" of Liqi Ji, "Walk and look" of Ling Gao. In this "National Art Exhibition", the proportion of printmaking art works in Jilin Province is $2.1 \%$, ranked 22th in the 28 provinces and groups, in the same period, 28 works were selected in Yunnan Province, There are 29 works selected in Heilongjiang Province, the huge gap between Jilin Province and other printmaking art provinces still exists.

\subsubsection{Printmaking Art of Jilin Province on "National Printmaking Art Exhibition"}

Biennial "National Printmaking Art Works Exhibition" is a professional individual exhibition organized by the Chinese artists association, in the academic sense, it has a certain degree of authority, in the five "National Printmaking Art Exhibition" on the past ten years, Jilin Province, the number of selected works of not more than five works, but it has always maintained a high quality of work, every time there are works to win the award.

In the Fourteenth "National Printmaking Art Exhibition" held in Sichuan Province in 1998, a total of 382 works selected, Jilin Province have a total of 5 works selected: "Love of the dream" of Lianmin Wang, "Autumn and dreams" of Shicheng Ji, "Symphony of destiny" of Sha Ge, "The trace of life" of Jinxiang Yang, "Dual phenomenon" of Yifan Li, accounted for 1.31\% of the total number of selected works. Yunnan Province, Heilongjiang Province and Zhejiang Province in the same period, there are all 20 works selected, in this exhibition, "Love of the dream" of Lianmin Wang was granted the Silver Award, "Autumn and Dreams" of Shicheng Ji was granted the Bronze Award.

Fifteenth session of the "National Printmaking Art Exhibition" held in Guangdong Province in 2000, a total of 323 works selected. Jilin Province have a total of 4 works selected: "The transformation of history and the leap from the material to the cultural spirit" of Lianmin Wang, "Three-people line" of Shicheng Ji, "The old man" of Sha Ge, "The whisper of silent" of Ling Gao. Printmaking art works in Jilin Province accounted for $1.24 \%$ of the total number of works, in the same period, 24 works were selected in Heilongjiang Province, Yunnan Province and Zhejiang Province all have 22 works selected. In the printmaking art works selected in Jilin province, "The transformation of history and the leap from the material to the cultural spirit" of Lianmin Wang was granted the Bronze Award.

The Sixteenth "National Printmaking Art Exhibition" held in Anhui Province in 2002, a total of 404 works selected. Jilin Province have a total of 2 works selected, "Biological love on dialogue" of Lianmin Wang, "Dunhuang dream" of Sha Ge, selected number of works accounted for the proportion of $0.5 \%$, the lowest percentage since 1998, and Zhejiang Province in the exhibition selected works as high as 30 works. At the same time, it is also in this session of the exhibition, "Biological love on dialogue" of Lianmin Wang wins the Gold Medal, and this is the first gold medal in Jilin Province in the national exhibition of printmaking art.

The Seventeenth "National Printmaking Art Exhibition" held in Guizhou Province in 2005, there are 376 works on display in this exhibition, there are 5 works selected in Jilin Province: "Shame series plants" of Lianmin Wang, "Lost to the Close" of Shujuan Guo, "Fantasy fly" of Shicheng Ji,"Savage civilization" of Yan Wang, "Fantasy transformation" of Changsen Zhu, selected number of works accounted for the proportion of 1.33\%, compared to the same period, Yunnan Province selected 24 works, Guizhou Province selected 26 works. In the current exhibition of printmaking art works, "Shame series plants" of Lianmin Wang was granted the Bronze Award.

The Eighteenth "National Printmaking Art Exhibition" held in Shanghai in 2007, a total of 263 pieces of prints were on display, there are only 2 works selected in Jilin Province, "Butterfly love flower" of Lianmin Wang, "Mountain day with the people" of Shicheng Ji, accounted for $0.76 \%$ of the 
number of exhibited works. In the same period, Guangdong Province selected 24 works, Zhejiang Province selected 19 works, and "Butterfly love flower" of Lianmin Wang won a prize for outstanding works.

The quality and quantity of the winning entries, to a certain extent, reflects the artistic level of the printmaking art in Jilin Province, throughout the ten years of the "National Printmaking Art Exhibition", the five exhibition, Jilin Province won one gold medal, one silver, three bronze, one excellent works, these winning entries are of high artistic level, rich ideological content, unique artistic language, but the winning artist is always focused on a few artists, winning works mainly for copper plate print, the printmaking art creation presents the individual level high, the overall level is low, copper plate print level outstanding, the level of other printmaking art needs to be improved.

\section{Analysis of the Current Situation of Education}

The education of printmaking art in Jilin Province mainly depends on education in colleges and universities. College printmaking art is a specific product of art institutions under the education system of our country, it is not equivalent to the traditional sense of the academic art, academic art is a popular concept at the end of last century, it is the artistic style of Europe was officially established at Academy of Fine Arts, there are essential differences between the two, in addition, there are difference in the classification of subjects, printmaking art education in our country, belonging to the fine arts, in the west, printmaking art is attributed to the category of design [8-10].

Printmaking art education in Jilin Province began in the last century in 40s, after more than and 60 years of development, at present, among the 44 Universities in Jilin Province, Northeast Normal University, Jilin College of the Arts, Yanbian University, Beihua University, Tonghua Normal University, a total of five colleges and universities opened a print art course, but most of these five institutions are only elective courses, only Northeast Normal University, Jilin College of the Arts opened a printmaking art professional and system teaching, these two colleges and universities each year to the social transmission of printmaking art graduates only a hundred people.

Teaching in Jilin Province is often use woodcut print and copper plate print, the limitation of equipment makes the lithographic stone print and silkscreen plate print of teaching is difficult to popularize. Over the years, Jilin Province is mainly in the woodcut print and copper plate print, lithographic stone print and silkscreen plate print are difficult to find representative works.

\section{Conclusion}

Jilin Province as our country's northeast old industrial base, in recent years, with the rapid economic development, the cause of culture and education has made great progress, under the background of the rapid economic and political background of Jilin Province, emerged a number of well-known printmaking art theorists, printmaking art creators and printmaking art educators, produced a large number of outstanding works of printmaking art, for the development of China's printmaking art has played a positive role in promoting. But, under the vigorous development of the national print environment, the educational causes of print in Jilin province is only dependent on universities, and have single creation subject, lack of communication channels, public acceptance of the existence of deviation and other issues. Quantitative analysis of quantity, proportion, quality and other data, for the works in calendar year "National Fine Art Exhibition" and "National Printmaking Art Exhibition", data statistics and theoretical reflection shows, printmaking art in Jilin Province performance as woodcut print and copper plate print creation level outstanding, lithographic stone print and silk screen plate print no representative works, overall development is relatively stable, but the overall development of Zhejiang, Yunnan, Heilongjiang and other provinces, there is a certain gap. The realistic situation of the printmaking art in Jilin Province is enough to cause the concern of the printmaking art world, worth further research and thinking, need to further find the crux of the development of printmaking art in Jilin Province, to provide theoretical support for breaking through the bottleneck of development as soon as possible. 


\section{Acknowledgment}

The authors gratefully thank the financial support by Research Project in Jilin Province "12th Five-year Plan" Education and Science Fund Project (GH150007); Youth fund of Northeast Normal University in philosophy and social science school projects (13QN028).

\section{References}

[1]. Paul Coldwell, “Hybrid practices within printmaking,” Journal of Visual Art Practice, 2015, pp. 175-178.

[2]. Michael F. Andrews, “The Art of Creative Printmaking,” Art Education, vol.17, 1964, pp. 23-25.

[3]. Lee Chesney, "Printmaking Today,” College Art Journal, vol.19, 1959, pp. 158-165.

[4]. Jordan Paper, "Religion and Art in Contemporary China,” Journal of Chinese Religions, vol.15, 1987, pp. 51-60.

[5]. Xiaoyang Zhao, "Rejuvenation after encounters between different artistic forms: a synopsis of studies of indigenization of Christian art in China,” Journal of Modern Chinese History, vol.8, 2014, pp. 258-271.

[6]. Yi Wen, Decai Zhao, "Some patient-related factors associated with late access to ART in China's free ART program,” AIDS Care, vol.23, 2011, pp. 1226-1235.

[7]. Wang Chunchen, "The Art of Anxiety: China's Social Transformation and the Uncertain Reception of Chinese Contemporary Art,” Journal of Visual Art Practice, vol.11, 2012, pp. 222-229.

[8]. Roberta Wue, "Selling the Artist: Advertising, Art, and Audience in Nineteenth-Century Shanghai,” The Art Bulletin, vol.91, 2009, pp. 463-480.

[9]. Dorothy McLaughlin, "Perceptions of Art Education in the People's Republic of China” Art Therapy, vol.8, 1991, pp. 7-11.

[10]. Gustave Von Groschwitz, "Cultural Identity, Artistic Empowerment, and the Future of Art in the Schools,” Design, vol.61, 1960, pp. 208-209. 